Suggested citation:

Fotheringham, S., Wells, L., \& Goulet, S. (2020). Strengthening the Circle: An International Review of Government Domestic Violence Prevention Plans and Inclusion of Indigenous Peoples. Violence Against Women. https://doi.org/10.1177/1077801219897846

\title{
STRENGTHENING THE CIRCLE: AN INTERNATIONAL REVIEW OF GOVERNMENT DOMESTIC VIOLENCE PREVENTION PLANS AND INCLUSION OF INDIGENOUS PEOPLES
}

Sarah Fotheringham PhD, RSW

Faculty of Social Work, University of Calgary

sffother@ucalgary.ca

450617 St. SW

Calgary, Alberta

T2T 4R2

Cell: 403-650-4056

Lana Wells MSW, RSW

Brenda Strafford Chair in the Prevention of Domestic Violence

Faculty of Social Work, University of Calgary

lmwells@ucalgary.ca

Sharon Goulet MSW, RSW

Faculty of Social Work, University of Calgary

Sharon.Goulet@calgary.ca

Key words: Indigenous Peoples, Domestic Violence, Violence Prevention, Policy 


\begin{abstract}
This study describes the level of government commitment in preventing domestic violence (DV) towards Indigenous women in countries of the Global North. Seventy-two government-endorsed DV prevention plans across 11 countries were analyzed. While over half of the plans acknowledged Indigenous peoples, the main discourse reinforced a western DV paradigm, reproduced negative stereotypes, and ignored systemic factors. Little consideration for intersectionality, the impact of colonization, or Indigenous worldviews was evident. Targeted prevention strategies were found but were disjointed and culturally inappropriate. Taken together, these findings suggest minimal government commitment and absence of cultural understanding regarding DV in Indigenous communities.
\end{abstract}




\section{INTRODUCTION}

Indigenous peoples ${ }^{1}$ across countries of the Global North encounter widespread adverse socio-economic conditions to a much greater degree than non-Indigenous populations. Many hold that this present-day reality is directly connected to a history of colonization that sought to disrupt, harm, and destroy Indigenous communities through the deliberate destruction of cultural practices, forced displacement from traditional territories, epidemics, and systemic violence (Baskin, 2012; Cripps \& Adams, 2014; Goulet et al., 2016; Jackson et al., 2015). These colonial practices continue today through systemic racism and structural oppression apparent in the numbers of Indigenous people incarcerated and Indigenous children caught up in child welfare systems (Sinha, Trocmé, Fallon, MacLaurin, Fast, Thomas Prokop et al., 2011). The prevalence of domestic violence (DV) ${ }^{2}$ both within these communities and towards Indigenous women and girls is a testament to the continuation of colonial policy and practices. Across countries such as Canada and Australia, rates of DV in Indigenous communities are significantly higher than nonIndigenous people, and interventions are commonly insufficient (Australian Institute of Health and Welfare, 2018; Department of Justice Canada, 2017).

Mainstream prevention efforts are underway across national and state governments as key actions and strategies aiming to reduce and eliminate DV are implemented. Given the prevalence of DV in Indigenous communities, the shared history of colonization in countries of the Global North, and the continued adverse socio-economic conditions of Indigenous peoples, this study examined whether current government-sanctioned violence prevention plans included Indigenous content. While many governments have focused their efforts in designing legislation to respond to domestic violence after it has occurred, this study targeted violence prevention frameworks that set policy direction and funding priorities focused on primary prevention. ${ }^{3}$ We asked whether these government-endorsed violence prevention plans included Indigenous peoples/communities, 
how DV was framed within this context, and what specific solutions and/or commitments were identified for Indigenous peoples.

Importantly, the objectives of this study are situated in a global context that locates DV as a part of the larger frame of violence against women (VAW). Defined as "any act of genderbased violence that results in, or is likely to result in, physical, sexual, or mental harm or suffering to women, including threats of such acts, coercion or arbitrary deprivation of liberty, whether occurring in public or private life” (UN Women, n.d., para. 2). To this aim, Indigenous women experiencing DV is part of the global VAW umbrella where culturally-specific experiences are embedded (Nixon, 2010). An example of this is the Missing and Murdered Indigenous Women (MMIW) $)^{4}$ inquiry taking place in Canada where the deaths and disappearances of possibly thousands of Indigenous women is under investigation.

Several other significant measures have occurred at the international level giving traction to this movement: one example is the Convention on the Elimination of all Forms of Violence Against Women (CEDAW), adopted in 1979 by the UN Generally Assembly but with continued oversight today. This work documented women's rights, defined discrimination, and provided an array of actions to end discrimination against women (Office of the High Commissioner Human Rights, 2018). Later in 2006, the United Nations released another essential document - the Secretary General's in-depth study on all forms of VAW - which highlighted the pervasiveness of this issue around the world while reinforcing the need for political commitment and combined international partnership towards its eradication (UN Women, 2007). Finally, in 2012, the Report of the Special Rapporteur on Violence Against Women, its Causes and Consequences was issued, examining state obligations to address VAW (Manjoo, 2012). As a result, of many of these international actions, nation and state governments have developed and implemented DV 
plans/frameworks designed to provide policy structure and direction with the aim of responding to, and preventing, VAW (UN Women, 2012).

Amid these international measures and government actions to prevent VAW, the UN has also been instrumental in supporting the work and activism of Indigenous peoples around the world. In 2008, the Declaration on the Rights of Indigenous Peoples was released (United Nations, 2008). This action constitutes a universal framework that outlines minimum standards assuring the wellbeing and survival of Indigenous peoples around the world. This was a momentous achievement for Indigenous political rights as it represented revolutionary transformation in the international order (Lightfoot, 2016). Among other fundamental guidelines in this Declaration, Article 22 indicates, "States shall take measures, in conjunction with Indigenous peoples, to insure that Indigenous women and children enjoy the full protection and guarantees against all forms of violence and discrimination” (p. 9). Although this is a nonbinding agreement, numerous countries - including all those examined in this study - have endorsed the Declaration. It is at this junction that we see VAW efforts converge with the rights of Indigenous peoples on an international scale.

This convergence represents the essence of intersectionality: a theoretical concept gaining greater acceptance in the DV field. An intersectional analysis originally stemmed from the recognition of the women's and civil rights movements in the United States examining the ways in which gender and race interact to create experience (Crenshaw, 1989). This approach was in direct challenge to the feminist idea at the time of a universal experience of being a woman, which largely reflected a white, middle-class perspective. It has since evolved to a conceptual tool that recognizes the interlocking effects of various forms of identity (race, class, sexuality, gender) and associated structures of inequality resulting in the identification and valuing of difference (Dill \& Kohlman, 2012). In the context of DV, intersectionality as an analytic tool has 
offered a new way forward by challenging the notion of a universal experience. Once viewed through a collective action lens where shared experience of DV was emphasized in order to create a needed social movement, Nixon and Humphreys (2010) suggest that intersectionality provides a conceptual tool that fosters a more nuanced understanding of DV and diversity of experience (and increased vulnerability) across differing groups of women.

An intersectional approach as an analytic tool thus underpins this current study. Indigenous women are indeed a group that is often rendered to the margins in mainstream conversation about DV, yet they are overrepresented in statistics and services (Australia Domestic and Family Violence Death Review Network, 2018; Department of Justice Canada, 2017; Te Puni KōKiri, 2017). In seeking to describe the current level of commitments in preventing domestic violence towards Indigenous women, we have applied an intersectional analysis of government sanctioned DV prevention plans from the Global North.

\section{Domestic Violence Prevalence}

DV is a major global public health issue that causes significant social and economic impact. Global estimates indicate that one in three women, over the course of their lifetime, have experienced physical and/or sexual violence from an intimate partner, or sexual violence from a non-partner (WHO, 2017). While there is no specific data on global prevalence of violence against Indigenous women and girls, we do know that Indigenous women and girls face heightened discrimination and are at increased risk for violence (UN Women, 2017, para.1), including femicide and disappearances (Manjoo, 2012).

At the country level, more information is available. In Canada for example, Indigenous women have a self-reported rate of intimate partner assault three times that of non-Indigenous women (10\% versus 3\%) (Department of Justice Canada, 2017). Correspondingly, national research from Australia demonstrates higher rates of DV amongst Aboriginal and Torres Strait 
Islander women than non-Indigenous (Australian Institute of Health and Welfare, 2018). Over a one-year period, one in seven Aboriginal and Torres Strait Islander women reported experiencing physical violence with one quarter of these reports indicating the violence from a cohabitating partner (Australian Bureau of Statistics, 2016). Further, Aboriginal and Torres Strait Islander men and women in Australia are overrepresented in domestic homicides as both victims (22\%) and perpetrators (20\%) (Australia Domestic and Family Violence Death Review Network, 2018).

Australia's close neighbour, New Zealand, also shares this pattern. Statistics on Māori peoples by Te Puni KōKiri (2017) suggest that the Māori are two times more likely than nonMāori to be a victim of intimate partner physical violence and experience coercive and controlling behaviours from a partner. Other available gender-specific statistics indicate that Māori women are higher users of women's shelter, and that Māori perpetrators of violence against family members constitute $45 \%$ of all offenders (Te Puni KōKiri, 2017).

The United States, through the National Institute of Justice, has data on American Indian and Alaska Native women and their experiences with domestic violence (Rosay, 2016). The lifetime prevalence rate of violence, which included sexual assault, physical violence, or psychological aggression from an intimate partner, and stalking, was an astounding $84.3 \%$. In regard to physical violence from an intimate partner alone, 55.5\% of American Indian and Alaska Native women had experienced it compared with $34.5 \%$ non-Hispanic, white-only women; a rate 1.6 times greater. An interesting yet important finding in this same work found that the majority of perpetrators of DV against American Indian and Alaska Native women were not an American Indian or Alaskan Native, but a member outside of this population (Rosay, 2016).

Finally, while national data appears to be absent for the Sami Indigenous communities of Scandinavia (Kuokkanen, 2015), smaller studies are demonstrating higher rates of violence 
among these Indigenous women than the general population (Eriksen, Hansen, Javo, \& Schei, 2015; Kuokkanen, 2015).

\section{Government \& Policy Response}

Scholars have been examining national and state policies on domestic violence for decades, with particular focus on criminal justice and legislative frameworks (Murray \& Powell 2009; Dobash \& Dobash, 2004), gender and feminism (Phillips, 2006; Corvo \& Johnson 2003; Abrar, Lovenduski \& Margetts 2000; Mann, 2008), and batterer intervention programs (Feder \& Wilson, 2005). Many of the studies dedicated to domestic violence policy investigation have done so using a comparative analysis involving two or more countries (Azis \& Moussa, 2016; Chappell \& Curtin, 2013; Corradi \& Stöckl, Tastsoglou, \& Abraham 2016; Franceschet, 2010). In 2002, based on a cross-national comparison of 36 governments, Weldon established that independent women’s movements strongly influenced whether governments took on issues of DV at the policy level. Indeed, she asserts, without feminist pressure, DV is seldom chosen as a government priority.

Htun and Weldon (2008) later conducted a global comparative analysis of VAW policies involving 70 countries over four decades. This research made similar conclusions to earlier work finding that independent feminist mobilization within civil society was the decisive factor for VAW domestic policy change. Weldon's earlier work found that minority women's movements, such as women of colour and Indigenous women in Canada and Australia, had much less influence on government policy noting that: “democratic governments appear to be more responsive to women of privileged groups than they are to women of marginalized subgroups” (Weldon, 2002, p. 159). Htun and Weldon's more recent work did not examine whether this has changed. 
Little scholarship is available on Indigenous communities and DV policy specifically. One notable exception is recent work by Murray and Powell (2009) who critically examined policy on family violence in Indigenous communities in Australia. They demonstrate how discourse on violence in Indigenous communities has been changing over time with increasing attention to understanding the unique experiences of Indigenous women.

\section{METHODS}

It is with the above in mind that this study transpired. We sought to answer the question: What is the current state of government commitment in preventing domestic violence towards Indigenous women? We examined whether governments recognize DV against Indigenous women, the current understanding about DV and Indigenous women in this context, and the proposed strategies and solutions to prevent DV against Indigenous women through governmentsanctioned violence prevention plans.

We centred this work within the pragmatic paradigm. Pragmatism takes an applied approach to research where the research question and the best approaches to answering the question guide the study process rather than concern with methodological alignment (Creswell 2007; Patton, 2002; Schatzman \& Struass, 1973). One of the best-known pragmatists, Patton (2002), explains, "Not all questions are theory based. Indeed, the quite concrete and practical questions of people working to make the world a better place...can be addressed without placing the study in one of the theoretical frameworks” (p. 136). Pragmatism is instead concerned with the applicability or usefulness of the research, and in many cases whether the research can be used for social or political change (Wicks \& Freeman, 1998). Since our research focused on government work in the area of DV prevention and the needs and experiences of Indigenous peoples, this proved the best way forward. 
Our primary method was documentation analysis of which there are several advantages as a data source. According to Bowen (2009) documents are generally more available and easier to access via the internet and public record, are unaffected by the research process, and offer exactness such as names, dates, and details than other methods. Limitations of this approach include documents that may be incomplete or inaccurate (Patton, 2002), may lack sufficient detail (Bowen, 2009), and can be vulnerable to 'biased selectivity' in that the documents available may be of a particular agenda or principle (Yin, 2003).

Government-endorsed national and regional DV prevention plans were collected across 11 countries and analyzed for content specific to Indigenous peoples. This type of plan was chosen because they represent primary prevention efforts at a national and state level, demonstrate government commitment to the issue, and indicate how a government aims to tackle DV through priorities for action (Wells, Goulet, \& Sandham, 2012).

Plans that are government-endorsed have also gone through a formalized internal process of development, agreement and approval, often at multiple levels within government, and often with budgets attached. These policy frameworks guide government decision making, set future direction, and identify and support the alignment of policies and practices both internal and external to government (Alberta Government, 2013). DV plans that are endorsed by national and regional governments thus offer the best barometer of government commitments to address violence against women (Weldon, 2002).

The collection of these documents and analysis of content occurred over two phases. Via the Internet, English-only government-endorsed plans since 2001 were collected across 11 countries. These were: Australia, Canada, New Zealand, United Kingdom (England, Scotland, Wales, and Northern Ireland), Republic of Ireland, the United States, Denmark, Norway, Sweden, Finland, and Iceland and included both federal and provincial/state level documents. From this 
process, 120 documents were identified. Exclusion criteria were then applied. Plans were excluded if: 1) The country does not have Indigenous peoples (i.e. United Kingdom); 2) The plan was not endorsed by the government (i.e. plans written by coalitions); 3) The plan focused on the prevention of sexual violence unless domestic violence was included; 4) The plan focused on domestic violence laws or legislation because these are forms of secondary and tertiary levels of prevention; 5) The plan was one that focused on “gender equality”, “empowerment of women”, or "women, peace and security"; 6) The plan was older than 2001; and 7) It was a progress report or update - only main plans and action plans were included. From this, the sample was reduced to 72 documents across seven countries (Appendix A).

The second phase of the methodology involved uploading the 72 documents into a mixed methodology analysis software program called Dedoose (Lieber \& Weisner, 2016). Here documents were coded into themes using specific search terms for Indigenous peoples: Aboriginal, Indigenous, First Peoples, First Nations, Native, Maori, Sami, Native American, Navajo, Pacific Islander, and American Indian. Plans were coded as either yes or no for inclusion of Indigenous peoples. If they did include this population, their content was further coded using a preliminary coding scheme with four main themes.

\section{Table 1 about here}

From this process, a significant amount of data was collected and analyzed. In addition to descriptive statistics, qualitative analysis was conducted using general qualitative methods consistent with that of the pragmatic approach, which included content analysis, first and second level coding, and categorizing (Patton, 2002).

One noteworthy limitation of this method is that not all government work on domestic violence is reflected in these plans. Also, those domestic violence plans that were not publicly 
available or locatable through the use of search terms on the Internet were not included in this analysis. Nonetheless, the collection of 72 documents from seven countries provides a sufficient sample from which the research questions can be answered.

\section{FINDINGS}

Distribution of Plans \& Acknowledgement of Indigenous Peoples

The current international distribution of the 72 plans is heavily weighted in favour of Australia, Canada, and the United States. These three countries have approximately 20 plans each. The remaining nations, including New Zealand and the Scandinavian countries, have between one and two plans. In total, out of all 72 plans, 63\% made some acknowledgement of Indigenous peoples. Looking specifically at the three countries with the most available plans, of Canada’s 23, all made some mention of Indigenous peoples. Out of Australia’s 20 plans, 14 did, while the United States had the least amount with only six plans out of 23 recognizing Indigenous populations.

The most common way Indigenous peoples were acknowledged in these plans was through description of DV prevalence rates. The vast majority of documents indicated that Indigenous populations had higher levels of violence including that of victimization and perpetration than non-Indigenous. Indigenous women were also discussed as more "at-risk” or "over-represented" in violence and homicide statistics than the general population.

Remaining documents recognized Indigenous peoples by acknowledging their unique needs or through identifying work with this population as a goal or outcome. In the first instance, commonly used terms included "special needs”, "special interests”, “diversity of needs”, “unique needs" and "specific challenges", or involved developing a "specific response" in relation to Indigenous peoples. Those plans that referred to Indigenous peoples only as an outcome or goal 
were those that provided very little additional discussion outside of service delivery for this population.

The Contextualization of Domestic Violence and Indigenous Peoples

In order to reveal the contextualization of DV within these plans, documents were analyzed for any reference to theories or causes of violence, or discussion regarding risk factors for DV in Indigenous communities. Despite well over half of the documents acknowledging Indigenous peoples, only seven plans discussed any cause or theory as to why DV occurs in such high rates amongst these communities.

The most common cause identified was the impact of historical trauma. State plans from Queensland discussed this history as well as two from Canada. These plans described a "legacy of trauma" and a "history of traumatic experiences" for example. A small number of plans identified colonization as well as fear, mistrust of government systems, and loss of land as additional root causes for violence amongst Indigenous peoples. Overall, any reference to causal or historical factors was very low.

Much like in the case of cause or theory, very few documents in our sample discussed risk factors. Plans from Australia and Canada were the exceptions. Of these plans, poverty and lowincome were the structural factors most commonly identified. Addictions and historical trauma were also cited as key issues contributing to high DV rates although plans often listed several social-economic factors together such as poverty, unemployment, poor health, and addictions with little further description or analysis given.

\section{$\underline{\text { Strategies \& Actions to Prevent Domestic Violence in Indigenous Communities }}$}

All plans were analyzed for whether they identified specific strategies or actions to prevent DV amongst Indigenous populations and communities. Out of the 72 plans, 49 of them had. While approximately 75 various actions and strategies were identified across documents, the 
most common fell into six main categories: service provision, capacity building, collaboration, research, promotion of Indigenous-led services, and engaging men and boys in violence prevention.

Establishing, enhancing, or expanding services to Indigenous peoples was the most common strategy found. While just over half of plans specified this, Australia (2012), Saskatchewan (2002), and Quebec (2012) discussed service provision the most. Some plans from Canada and Australia specified service expansion for Indigenous peoples in remote areas. Although types of services ranged vastly, the two most frequent were housing/shelter and social marketing/education campaigns.

Capacity building was the second most popular prevention strategy described. In general, this theme referred to activities that involve developing and strengthening skills, abilities and capabilities of Indigenous communities to respond directly within their own communities, to DV. Specific capacity-building actions were outlined such as DV training for Indigenous peoples, fostering the leadership of Indigenous women, building Indigenous community capacity to deliver services, and Indigenous awareness training for service providers.

Collaboration was a third identified prevention strategy. This theme signified activity that involved working together towards a shared vision. In this way, it reflected working across government groups or with local Indigenous communities. Intergovernmental collaboration was one type described mostly in Canadian plans. This involved work that crossed government and non-government departments, and Indigenous organizations and communities. Another frequent type of collaboration encompassed activities related to advising, consulting, or engaging with Indigenous peoples/groups. Finally, promoting collaboration across intervention services (nongovernment organizations) was another notable strategy under this theme. 
Conducting research and evaluation was a fourth theme that involved activities such as needs assessments, best and evidence-based practice identification, program evaluation, and community-based research. Citing a lack of available data specific to Indigenous groups, Finland, Norway, Newfoundland, and North Dakota proposed to conduct research to fill this gap. Other government documents planned research initiatives to determine service needs and to improve service provision.

Twelve plans emphasized the need for Indigenous-led services. Documents from New Zealand, Queensland, and eight Canadian provinces specified that services should be designed and implemented by Indigenous peoples, specifically for Indigenous peoples. Excerpts from many of these plans recognize the unique needs of many Indigenous communities as well as the importance of including cultural worldviews. These plans also indicated that services need to be culturally appropriate, holistic, and include traditional healing practices.

The final strategy identified by a small number of plans was the engagement of Indigenous men and boys in DV prevention. The most common approach was to involve men in the promotion of non-violence activities such as through media campaigns. Another method was promoting anti-violence male leadership in Indigenous communities. Beyond mention of such strategies, little additional details were provided.

\section{DISCUSSION}

\section{Indigenous Recognition Limited}

One important finding from this study was around acknowledgement of Indigenous peoples. While Indigenous peoples were recognized in over half of the plans, it was primarily concentrated within two countries: Canada and Australia. The United States, in contrast, seldom identified or recognized this population in their regional domestic violence plans. Similarly, the Scandinavian countries made little mention - mainly outlining a lack of information on Sami 
people which is consistent with literature that suggests violence against Indigenous women is not a priority for political institutions (Kuokkanen, 2015).

We recognize that geography matters, and the distribution of Indigenous people vary from region to region, and this variance might be used to explain representation in DV plans. We, however, maintain all government-endorsed plans included in this review should recognize and acknowledge Indigenous women and their communities due to the shared history of colonization, ongoing socio-economic challenges (including high rates of DV), and international commitments to the Rights of Indigenous Peoples. Further research into the geographic distribution of Indigenous peoples affecting representation in government-endorsed DV plans would be an important way forward.

\section{Discourse Falls Short of the Recognition of Intersectionality}

Another key finding relates to the lack of an intersectional approach in the majority of plans reviewed. Domestic violence and Indigenous peoples were largely characterized in relation to prevalence rates, or in referring to these communities as "vulnerable" with "specific/unique" needs. Little intersectional, contextual, or structural analysis was described. In particular, reference to the legacy and impact of colonial government-sanctioned policies and practices that were intent on destroying Indigenous communities, such as residential schools, was mostly absent. This, despite the wealth of literature - much of which is written by Indigenous peoples on the relationship between this legacy of colonization, and the resulting intergenerational trauma and DV of today (Assembly of First Nations, 1994; Baskin, 2012; Brownridge, 2008; Cripps \& Adams, 2014; Goulet et al., 2016; Jackson, Coleman, Strikes with A Gun \& Sweet Grass, 2015; Kuokkanen, 2015; LaBoucane-Benson, Sherren \& Yerichuk, 2017; Olsen \& Lovett, 2016; Victorian Health Promotion Foundation, 2007; Wells \& Goulet, 2011). This finding suggests that more often than not, the application of an intersectional approach to DV is missing. It appears 
from the document review, the dominant priority for governments is to continue to reinforce policies and services that are, "constructed to meet the needs of the dominant class...able-bodied, heterosexual, white, English-speaking, middle-class women” (Sinclair, 2012, p. 16).

What's more, identifying Indigenous peoples as a high-risk group focused only on prevalence rates or special needs reduces the issue of DV to an individual level (and response), ignoring larger structural and societal contributing factors. This perception reinforces negative, demeaning, and racist stereotypes about Indigenous peoples implying that DV is inherent to these communities or is customary (Cripps, 2007; Olsen \& Lovett, 2016). The absence of an intersectional analysis within these plans is evident in that the dominant, universal perspective of DV centres on it as a private form of violence, thereby excluding public and structural forms often experienced by Indigenous women and other marginalized groups (Sinclair, 2012). Indigenous Worldviews are Absent

It is perhaps of no surprise then that in line with an inadequate intersectional approach to DV, Indigenous worldviews are also largely absent in government plans. Outside of a few exceptions, plans were framed in a dominant western paradigm of DV. Indigenous scholars are clear that Indigenous worldviews are distinct from that of the dominant western perspective (Baskin, 2012; Cripps, 2007; Jackson et al., 2015).

Aside from the explicit link to the legacy of colonization and the impact of intergenerational trauma described earlier, Indigenous worldviews place emphasis on family and community over the individual: "The individual is seen in the context of the family, which is seen in the context of the community...when an individual is harmed, it is believed that this affects all others in that person's family and community" (Baskin, 2012, p. 149). A holistic worldview is often used to reflect this perspective in that it stresses DV as a community-level problem (Olsen \& Lovett, 2016) where all people need to heal from the violence, not just the person directly hurt 
(Cripps, 2007). In contrast, the dominant western narrative of DV involves two people - a victim (usually female) and a perpetrator (usually male) ${ }^{5}$ - whose separation is a key part of intervention, and the majority of policies and services are set up in response to this gender dyad. A holistic worldview seeks harmony and balance for the family and community in comparison to one that is based in crisis, punishment, and separation (Baskin, 2012; Cripps, 2007).

\section{Service Response Appears Fractured}

The disconnect between Indigenous worldviews and the dominant DV paradigm results in what appears to be a fractured service system according to government-endorsed DV plans. Our review found over 75 different actions and strategies targeted at Indigenous peoples in government DV plans raising the question about whether so many different strategies can provide a cohesive, consistent, and effective service response. While our analysis determined six common strategies from these 75, we found they typically are not offered in any organized manner, and do not comprehensively reflect Indigenous worldviews. Further research exploring on-the-ground services is needed, specifically examining if they connect with government-endorsed plans, if there is evidence of effectiveness, and how they reflect principles of Indigenous worldviews.

Literature suggests worldviews are fundamental to any service provided to Indigenous peoples, such as the need for a holistic approach to intervention (Jackson et al., 2015). They must involve all people - men, women and children - whether victims or offenders, and not work from an isolationist, didactic, individualist perspective (Baskin, 2012). Cripps (2007) explains, “Any response to violence in Indigenous communities must recognise that men, women and children are interconnected through a system of kinship and mutual obligations, and remain so even after violence has occurred” (p. 11).

Engaging men and boys in DV work is a recent and growing focal point of mainstream DV services (Wells et al., 2013) despite researchers long stressing the importance of their 
involvement from a prevention standpoint (Crooks, Goodall, Hughes, Jaffe, \& Baker 2007; DeKeseredy \& Kelly, 1995; DeKeseredy, Schwartz, \& Alvi, 2000; Groth, 2001; Kaufman, 2001). Notably, only a small number of plans discussed this as a prevention strategy. In fact, this received the least attention across the service themes, and was not presented in a way that reflected or respected a holistic approach.

What's more, according to the literature, services must be based in and led by Indigenous communities (Baskin, 2012; Proulx \& Perrault, 2000; Jackson et al., 2015). However, only a few DV plans made this explicit in their strategy, suggesting that consultation and engagement is often overlooked or undervalued in government-endorsed plans. Some plans did discuss actions to build capacity in Indigenous communities - a strategy somewhat supported by the literature (Cripps, 2007; ONWA \& OFIFC, 2007; Shea, Nahwegahbow, A., \& Andersson, 2010). For example, there is indication that Indigenous peoples want a greater role in DV response and prevention (Olsen \& Lovett, 2016) through increasing positive community leadership (Cripps, 2007; ONWA \& OFIFC, 2007), and awareness training for non-Indigenous peoples in DV services specifically understanding colonization and its impact (Day, Jones, Nakata, \& McDermott, 2012; Jackson et al., 2015; Jones, 2008). Unfortunately, common notions of capacity building still emulate the dominant paradigm of DV service delivery on a people that have a differing worldview.

Although evaluation of Indigenous prevention programs was beyond the scope of this paper, the now-defunded Aboriginal Healing Foundation (2006) in Canada established a set of best practices for culturally responsive healing practices. These included activities such as family circles, group healing, traditional healing, and the use of Aboriginal languages, storytelling, engagement of Elders, and time on land. Further exploration of these characteristics as well as their application within violence prevention programs is warranted. 


\section{Structural Change is an Imperative}

Baskin (2012) outlines the feminist standpoint that violence against women occurs because of systemic gender inequality and patriarchy, and until this is abolished, DV will continue. She also argues that structural and systemic racism against Indigenous peoples contributes to DV. As such, structural change is required and in particular for Baskin, the notion of self-governance: "Family violence in our communities will not end until racial equality in the form of self-government...is restored” (Baskin, 2012, p. 159).

Acknowledging and addressing structural racism was seldom seen in the DV plans supporting our claim that government plans are situated in the outdated perception of DV as a universal experience for women which reflects the dominant class. Instead, the closest action to system-level work evident in the plans was a strategy targeting multi-sectoral collaboration in response to related adverse socio-economic conditions. Indeed, it is well established that challenges such as poverty, lack of quality housing, overcrowding, resource access and addiction are disproportionately experienced by Indigenous peoples due to the history of colonization and racism which are interrelated to high rates of DV (Baskin, 2012; Brownridge, 2008; Jones, 2008; Olsen \& Lovett, 2016). As such, service collaboration across these service sectors is an essential component (Jones, 2008). Yet this action does little to address structural racism and oppression experienced by Indigenous peoples across interrelated systems. This lack of targeted structural change, in addition to the lack of recognition of Indigenous worldviews contributes to a fractured government response, thus providing a strong case for the meaningful application of an intersectional approach to government violence prevention plans.

\section{CONCLUSION}

In conclusion, the majority of government-sanctioned violence prevention plans failed to deliver on a comprehensive commitment to Indigenous peoples. The few exceptions include 
plans from Queensland, Australia, Quebec, Saskatchewan, and British Columbia, Canada. These plans emphasize combinations of collaboration and engagement with Indigenous communities, Indigenous-specific programming, as well as structural and policy change but not in any comprehensive or holistic manner. They do, however, provide frameworks from which we can build.

The small number of government plans indicating commitment to working with Indigenous peoples in the prevention of DV should be troubling to advocates. When governmentsanctioned DV plans ignore, minimize, or misrepresent DV in Indigenous communities, an absence of specific strategies and actions follows, and little changes.

The Nehiyaw, or Cree word Wahkotiwin, can be translated into the cultural principles of discipline, responsibility, respect, and accountability. Prior to contact, when interpersonal conflict occurred, the lifestyle of Wahkotiwin created ways and means to address problems at the individual and communal level. Governments need to not only acknowledge the past, but must also be allies in the rebuilding of Indigenous paradigms such as Wahkotiwin, so that communities can begin to rebuild what was lost. Indigenous people must be given the financial means and power to move in directions that make sense for us - not what is most expedient for governments. As Haudenosaunee scholar Dr. Taiaiake Alfred has expressed, "The problems of Indigenous communities have never been solved by government and they never will be” (personal conversation, October 24th, 2015). Governments in partnership with Indigenous communities can however act as allies to strengthen the circle of discipline, responsibility, respect, and accountability necessary to address domestic violence for all Indigenous peoples. 


\section{NOTES}

${ }^{1}$ Indigenous communities, peoples, and nations are those which, having a historical continuity with pre-invasion and pre-colonial societies that developed on their territories, consider themselves distinct from other sectors of the societies now prevailing on those territories, or parts of them. They form at present non-dominant sectors of society and are determined to preserve, develop, and transmit to future generations their ancestral territories and their ethnic identity as the basis of their continued existence as peoples in accordance with their own cultural patterns, social institutions, and legal system (Martínez Cobo, 1982).

${ }^{2}$ Domestic violence (DV) is the term used throughout this paper to refer to intimate partner violence, i.e. one form of violence against women which includes physical, emotional, or sexual abuse by a current or former partner or spouse (National Center for Injury Prevention and Control, 2003). In this paper, we also use "family violence” and "violence against women” to refer to broader types of violence that include, but are not limited to, domestic violence. ${ }^{3}$ Primary prevention in this context means reducing the number of new instances of family violence by intervening before any violence has occurred. Primary prevention "relies on identification of the underlying, or 'upstream,' risk and protective factors for intimate-partner violence and/or sexual violence, and action to address those factors” (Harvey, Garcia-Moreno, \& Butchart, 2007, p. 5).

${ }^{4}$ See National Inquiry into Missing and Murdered Indigenous Women and Girls at http://www.mmiwg-ffada.ca

${ }^{5}$ The authors wish to acknowledge the shortcomings of the gender dyad narrative (men are perpetrators and women are victims) that is prevalent in the domestic violence field. This narrative reinforces men are problematic and women need to be protected, thus reinforcing the patriarchy. This description does not challenge the underlying problems of unequal patriarchal 
power relations, the relationship between masculinity/femininity, and patriarchal power and the connection to VAW. For a further discussion, please see https://www.novapublishers.com/catalog/product_info.php?products_id=52859. 


\section{REFERENCES}

Aboriginal Healing Foundation. (2006). Promising healing practices in Aboriginal communities.

Retrieved from http://www.ahf.ca/downloads/final-report-vol-3.pdf

Abrar, S., Lovenduski, J., \& Margetts, H. (2000). Feminist ideas and domestic violence policy change. Political Studies, 48(2), 239-262. [DOI: 10.1111/1467-9248.00258]

Alberta Government. (2013). Alberta’s social policy framework. Retrieved from http://www.humanservices.alberta.ca/documents/spf-full-report.pdf

Assembly of First Nations. (1994). Breaking the silence: An interpretive study of residential school impact and healing as illustrated by the stories of the First Nations individuals. Ottawa, ON: Assembly of First Nations Health Commission.

Australian Bureau of Statistics. (2016). National Aboriginal and Torres Strait Islander Social Survey 2014-2015. ABS cat. No. 4714.0. Canberra: ABS.

Australia Domestic and Family Violence Death Review Network. (2018). Data Report. Retrieved from https://aifs.gov.au/cfca/2018/06/04/report-australian-domestic-and-family-violence-death-reviewnetwork-data-report-2018

Australian Institute of Health and Welfare. (2018). Family, domestic and sexual violence in Australia. Retrieved from https://www.aihw.gov.au/getmedia/d1a8d479-a39a-48c1-bbe24b27c7a321e0/aihw-fdv-02.pdf.aspx?inline=true

Azis, S. A., \& Moussa, J. (2016). Due diligence framework on state accountability for eliminating violence against women. Retrieved on January 16, 2018 from http://www.duediligenceproject.org/ewExternalFiles/Due\%20Diligence\%20Framework\%20Repo rt\%20Z.pdf 
Baskin, C. (2012). Systemic oppression, violence \& healing in Aboriginal families and communities. In R. Alaggia \& C. Vine (Eds.). Cruel but not unusual: Violence in Canadian families. A sourcebook for educators \& practitioners (pp. 147-178). Kitchener: Wilfred Laurier University Press.

Bowen, G. A. (2009). Document analysis as a qualitative research method. Qualitative Research Journal, 9(2), 27-40. [DOI: 10.3316/QRJ0902027]

Brownridge, D. A. (2008). Understanding the elevated risk of partner violence against Aboriginal women: A comparison of two nationally representative surveys of Canada. Journal of Family Violence, 23(5), 353-367. [DOI 10.1007/s10896-008-9160-0]

Chappell, L., \& Curtin, J. (2013). Does federalism matter? Evaluating state architecture and family and domestic violence policy in Australia and New Zealand. Publius: The Journal of Federalism, 43(1), 24-43. [DOI:10.1093/publius/pjs030]

Corradi, C., Stöckl, H., Tastsoglou, E., \& Abraham, M. (2016). The lessons of history: The role of the nation-states and the EU in fighting violence against women in 10 European countries. Current Sociology, 64(4), 671-688.

Corvo, K., \& Johnson, P. J. (2003). Vilification of the "batterer": How blame shapes domestic violence policy and interventions. Aggression and Violent Behavior, 8(3), 259-281. [DOI: 10.1016/S1359-1789(01)00060-X]

Crenshaw, K. (1989). Demarginalizing the intersection of race and sex: A black feminist critique of antidiscrimination doctrine, feminist theory and antiracist politics. Chicago Legal Forum, 139167.

Creswell, J. W. (2007). Qualitative inquiry \& research design: choosing among five approaches (2nd ed). Thousand Oaks: Sage Publications. 
Cripps, K. (2007). Indigenous family violence: from emergency measures to committed long-term action. Australian Indigenous Law Review, 11(2), 6-18.

Cripps, K., \& Adams, M. (2014). Family violence: Pathways Forward. In P. Dudgeon, H. Milroy, \& R. Walker (Eds.), Working together: Aboriginal and Torres Strait Islander mental health and wellbeing principles and practice (pp. 399-416). West Perth, WA: Kulunga Research Network. Retrieved on January 16, 2018 from http://aboriginal.telethonkids.org.au/kulunga-researchnetwork/working-together-2nd-edition-2014

Crooks, C. V., Goodall, G. R., Hughes, R., Jaffe, P. G., \& Baker, L. L. (2007). Engaging men and boys in preventing violence against women: Applying a cognitive-behavioral model. Violence Against Women, 13(3), 217-239. [DOI: 10.1177/1077801206297336]

Day, A., Jones, R., Nakata, M., \& McDermott, D. (2012). Indigenous family violence: An attempt to understand the problems and inform appropriate and effective responses to criminal justice system intervention. Psychiatry, Psychology and Law, 19(1), 104-117.

DeKeseredy, W. S., \& Kelly, K. (1995). Sexual abuse in Canadian university and college dating relationships: The contribution of male peer support. Journal of Family Violence, 10(1), 41-53. [DOI: 10.1007/BF02110536]

DeKeseredy, W. S., Schwartz, M. D., \& Alvi, S. (2000). The role of profeminist men in dealing with woman abuse on the Canadian college campus. Violence Against Women, 6(9), 918-935. [DOI: 10.1177/10778010022182218]

Department of Justice Canada. (2017). Victimization of indigenous women and girls. Retrieved from http://www.justice.gc.ca/eng/rp-pr/jr/jf-pf/2017/july05.html

Dill, B.T., \& Kohlman, M.H. (2012). Intersectionality: A transformative paradigm in feminst theory and social justice. In S. N. Hesse-Biber (Ed.), Handbook of feminist research: Theory and praxis (2 ed., pp. 154-174). Thousand Oaks, CA: Sage. 
Dobash, R. P., \& Dobash, R. E. (2004). Women’s violence to men in intimate relationships. British Journal of Criminology, 44, 324-349. [DOI: 10.1093/bjc/azh026]

Eriksen, A. M. A., Hansen, K. L., Javo, C., \& Schei, B. (2015). Emotional, physical and sexual violence among Sami and non-Sami populations in Norway: The SAMINOR 2 questionnaire study. Scandinavian Journal of Public Health, 43(6), 588-596. [DOI:

$10.1177 / 1403494815585936]$

Feder, L., \& Wilson, D. B. (2005). A meta-analytic review of court-mandated batterer intervention programs: Can courts affect abusers’ behavior? Journal of Experimental Criminology, 1(2), 239_ 262. [DOI: 10.1007/s11292-005-1179-0]

Franceschet, S. (2010). Explaining domestic violence policy outcomes in Chile and Argentina. Latin American Politics and Society, 52(3), 1-29. [DOI: 10.1111/j.1548-2456.2010.00088.x]

Goulet, S., Lorenzetti, L., Walsh, C. A., Wells, L., \& Claussen, C. (2016). Understanding the environment: Domestic violence and prevention. The First Peoples Child \& Family Review, 923.

Groth, B. (2001). Lessons from the spiritual lives of men who work in the movement to end violence against women and children. Journal of Religion \& Abuse, 2(1), 5-31. [DOI: 10.1300/J154v02n01_02]

Harvey, A.; Garcia-Moreno, C.; Butchart, A. (2007). Primary Prevention of Intimate-Partner Violence and Sexual Violence: Background Paper for WHO Expert Meeting May 2-3, 2007. (Geneva: World Health Organization). Retrieved May 1, 2013 from http://www.who.int/violence_injury_prevention/publications/violence/IPV-SV.pdf. 5. 
Htun, M., \& Weldon, S. (2012). The Civic Origins of Progressive Policy Change: Combating Violence against Women in Global Perspective, 1975-2005. American Political Science Review, 106(3), 548-569.

Jackson, E. L., Coleman, J., Strikes with A Gun, G., \& Sweet Grass, D. (2015). Threading, stitching, and storytelling: Using CBPR and Blackfoot knowledge and cultural practices to improve domestic violence services for Indigenous women. Journal of Indigenous Social Development, $4(1)$.

Jones, L. (2008). The distinctive characteristics and needs of domestic violence victims in a Native American community. Journal of Family Violence, 23(2), 113-118. [DOI: 10.1007/s10896-0079132-9]

Kaufman, M. (2001). Building a movement of men working to end violence against women. Development, 44(3), 9-14. [DOI: 10.1057/palgrave.development.1110254]

Kuokkanen, R. (2015). Gendered violence and politics in Indigenous communities: The cases of Aboriginal people in Canada and the Sámi in Scandinavia. International Feminist Journal of Politics, 17(2), 271-288. [DOI: 10.1080/14616742.2014.901816]

LaBoucane-Benson, P., Sherren, N., Yerichuk, D. (2017). Trauma, Child Development, Healing and Resilience: A review of literature with focus on Indigenous peoples and communities. Edmonton, Alberta: PolicyWise for Children \& Families.

Lieber, E., \& Weisner, T. S. (2016). Dedoose Version 7.0.23. Los Angeles, CA: SocioCultural Research Consultants, LLC. Retrieved on January 16, 2018 from http://www.dedoose.com/ Lightfoot, S. (2016). Global indigenous politics: A subtle revolution. London: Routledge, Tyalor \& Francis Group. 
Manjoo, R. (2012). Report of the Special Rapporteur on violence against women, its causes and consequences. Retrieved from https://www.ohchr.org/Documents/Issues/Women/A.HRC.20.16_En.pdf

Mann, R. M. (2008). Men’s rights and feminist advocacy in Canadian domestic violence policy arenas: Contexts, dynamics, and outcomes of antifeminist backlash. Feminist Criminology, 3(1), 44-75. [DOI: 10.1177/1557085107311067]

Martínez Cobo, J. (1983). Study of the Problem of Discrimination Against Indigenous Populations Final report submitted by the Special Rapporteur. Retrieved on January 16, 2018 from https://www.un.org/development/desa/indigenouspeoples/publications/martinez-cobo-study.html

Murray, S., \& Powell, A. (2009). “What's the problem?”: Australian public policy constructions of domestic and family violence. Violence Against Women, 15(5), 532-552. [DOI:

$10.1177 / 1077801209331408]$

National Center for Injury Prevention and Control. (2003). Costs of Intimate Partner Violence against Women in the United States. Atlanta (GA): Centers for Disease Control and Prevention.

Nixon, J., \& Humphreys, C. (2010). Marshalling the Evidence: Using Intersectionality in the Domestic Violence Frame. Social Politics, 17(2), 137-158.

Office of the High Commissioner Human Rights. (2018). Convention on the elimination of all forms of discrimination against women. Retrieved from https://www.ohchr.org/EN/ProfessionalInterest/Pages/CEDAW.aspx

Olsen, A., \& Lovett, R.. (2016). Existing knowledge, practice and responses to violence against women in Australian Indigenous communities: state of knowledge paper. Alexandria, NSW: ANROWS. Retrieved on January 16, 2018 from https://d2c0ikyv46o3b1.cloudfront.net/anrows.org.au/s3fspublic/FINAL\%2002.16_3.2\%20AIATSIS\%20Landscapes\%20WEB.pdf 
Ontario Native Women’s Association, \& The Ontario Federation of Indian Friendship Centres

[ONWA \& OFIFC]. (2007). A Strategic Framework to End Violence Against Aboriginal Women.

Retrieved on January 16, 2018 from

http://www.oaith.ca/assets/files/Publications/Strategic_Framework_Aboriginal_Women.pdf

Patton, M. Q. (2002). Qualitative research and evaluation methods (3 ed). Thousand Oaks, Calif:

Sage Publications.

Phillips, R. (2006). Undoing an activist response: feminism and the Australian government's domestic violence policy. Critical Social Policy, 26(1), 192-219. [DOI: 10.1177/0261018306059771]

Proulx, J., \& Perrault, S. (2000). No place for violence: Canadian Aboriginal alternatives. Halifax, N.S.: Fernwood.

Rosay, A. (2016). Violence against American Indian and Alaska Native women and men. Retrieved from https://nij.gov/journals/277/Pages/violence-against-american-indians-alaska-natives.aspx

Schatzman, L., \& Strauss, A. L. (1973). Field research; strategies for a natural sociology. Englewood Cliffs, N.J: Prentice-Hal.

Shea, B., Nahwegahbow, A., \& Andersson, N. (2010). Reduction of family violence in Aboriginal communities: A systematic review of interventions and approaches. Pimatisiwin, 8(2).

Sinclair, D. (2012).Voices of women from the margins: Rexamining violence against women. In R. Alaggia \& C. Vine (Eds.). Cruel but not unusual: Violence in Canadian families. A sourcebook for educators \& practitioners. (pp. 13-42). Kitchener: Wilfred Laurier University Press.

Sinha, V., Trocmé, N., Fallon, B., MacLaurin, B., Fast, E., Thomas Prokop, S. et al. (2011). Kiskisik Awasisak: Remember the Children - Understanding the Overrepresentation of First Nations Children in the Child Welfare System. Ontario: Assembly of First Nations.

Te Puni KōKiri. (2017). Understanding family violence: Māori in Aotearoa New Zealand. Retrieved from https://tpk.govt.nz/en/a-matou-mohiotanga/health/maori-family-violence-infographic 
UN Women. (n.d). Violence against women: A brief overview of the United Nations and violence against women. Retrieved from http://www.un.org/womenwatch/daw/vaw/v-overview.htm

UN Women. (2007). The Secretary-General's in-depth study on all forms of violence against women. Retrieved from http://www.un.org/womenwatch/daw/vaw/SGstudyvaw.htm

UN Women. (2012). Handbook for national action plans on violence against women. New York, NY: UN Women.

UN Women. (2017). Ending violence against Indigenous women and girls. Retrieved from http://untf.unwomen.org/en/digital-library/publications/2017/08/ending-violence-againstindigenous-women-and-girls

United Nations. (2008). United Nations declaration of the rights of indigenous peoples. New York, NY. Retrieved on January 16, 2018 from http://www.un.org/esa/socdev/unpfii/documents/DRIPS_en.pdf

Victorian Health Promotion Foundation. (2007). Preventing violence before it occurs a framework and background paper to guide the primary prevention of violence against women in Victoria. Retrieved on January 16, 2018 from https://www.vichealth.vic.gov.au/media-andresources/publications/preventing-violence-before-it-occurs

Weldon, S. L. (2002). Protest, policy, and the problem of violence against women: a cross-national comparison. Pittsburgh, Pa: University of Pittsburgh Press.

Wells, L., Carolo, H., Dinner, T., Jones, C., Minerson, T., \& Esina, E. (2013). Engaging men and boys in domestic violence prevention: Opportunities and promising approaches. Calgary, AB: The University of Calgary, Shift: The Project to End Domestic Violence.

Wells, L., \& Goulet, S. (2011). Shift: The Project to End Domestic Violence: Research in the Calgary Aboriginal community (No. 004-12-16). Calgary, AB: The Centre for Criminology and Justice Research, Mount Royal University. 
Wells, L., Goulet, S., \& Sandham, S. (2012). Surveying the Landscape: Domestic Violence Plans from Around the World. Calgary, AB: The University of Calgary, Shift: The Project to End Domestic Violence.

Wicks, A. C., \& Freeman, R. E. (1998). Organization studies and the new pragmatism: Positivism, anti-positivism, and the search for ethics. Organization Science, 9(2), 123-140. [DOI: 10.1287/orsc.9.2.123]

World Health Organization. (2017). Violence against women: Key facts. Retrieved from http://www.who.int/news-room/fact-sheets/detail/violence-against-women

Yin, R. K. (2003). Case study research: design and methods (3rd ed). Thousand Oaks, Calif: Sage Publications. 


\section{Appendix A: List of National and Regional DV plans Included in the Study}

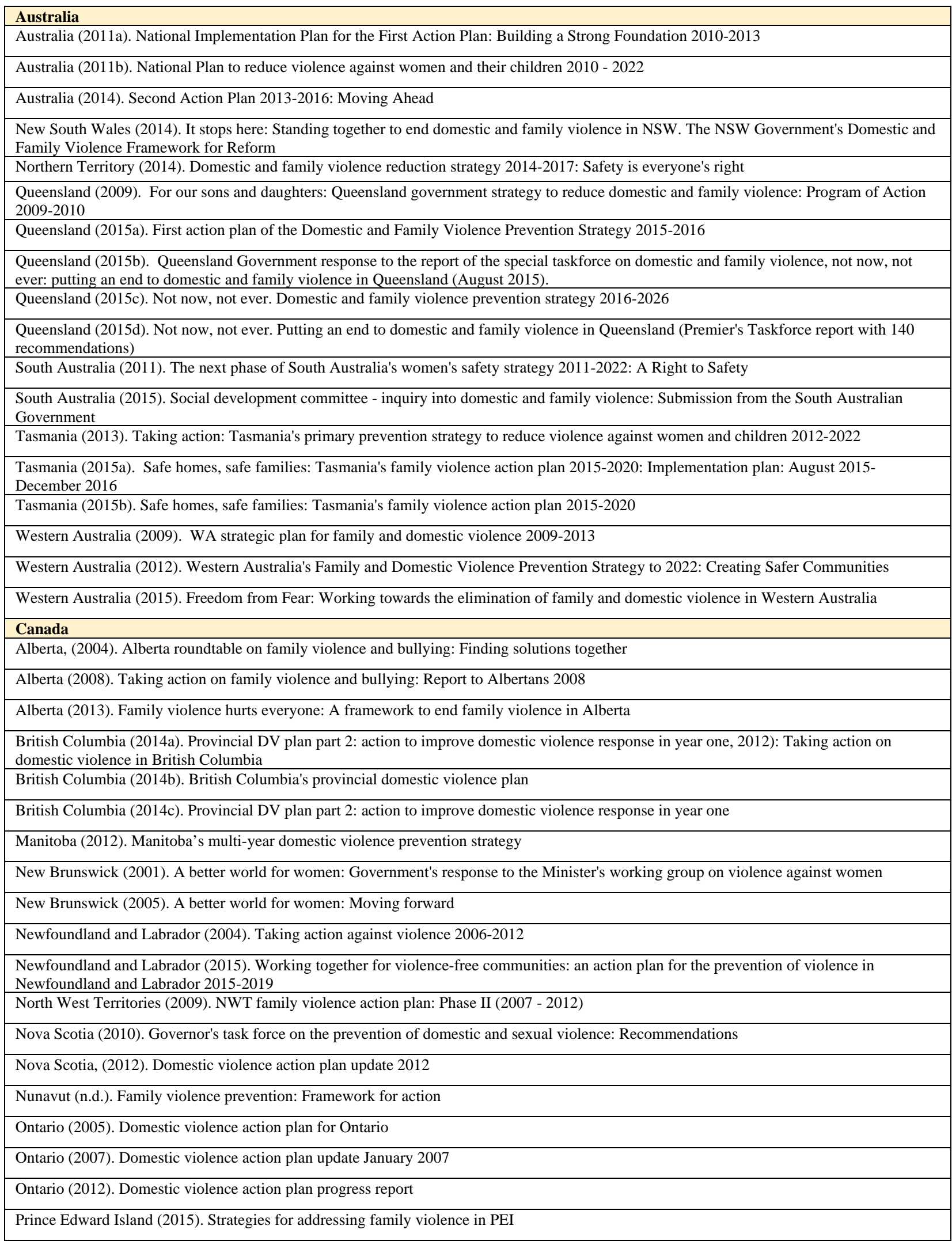




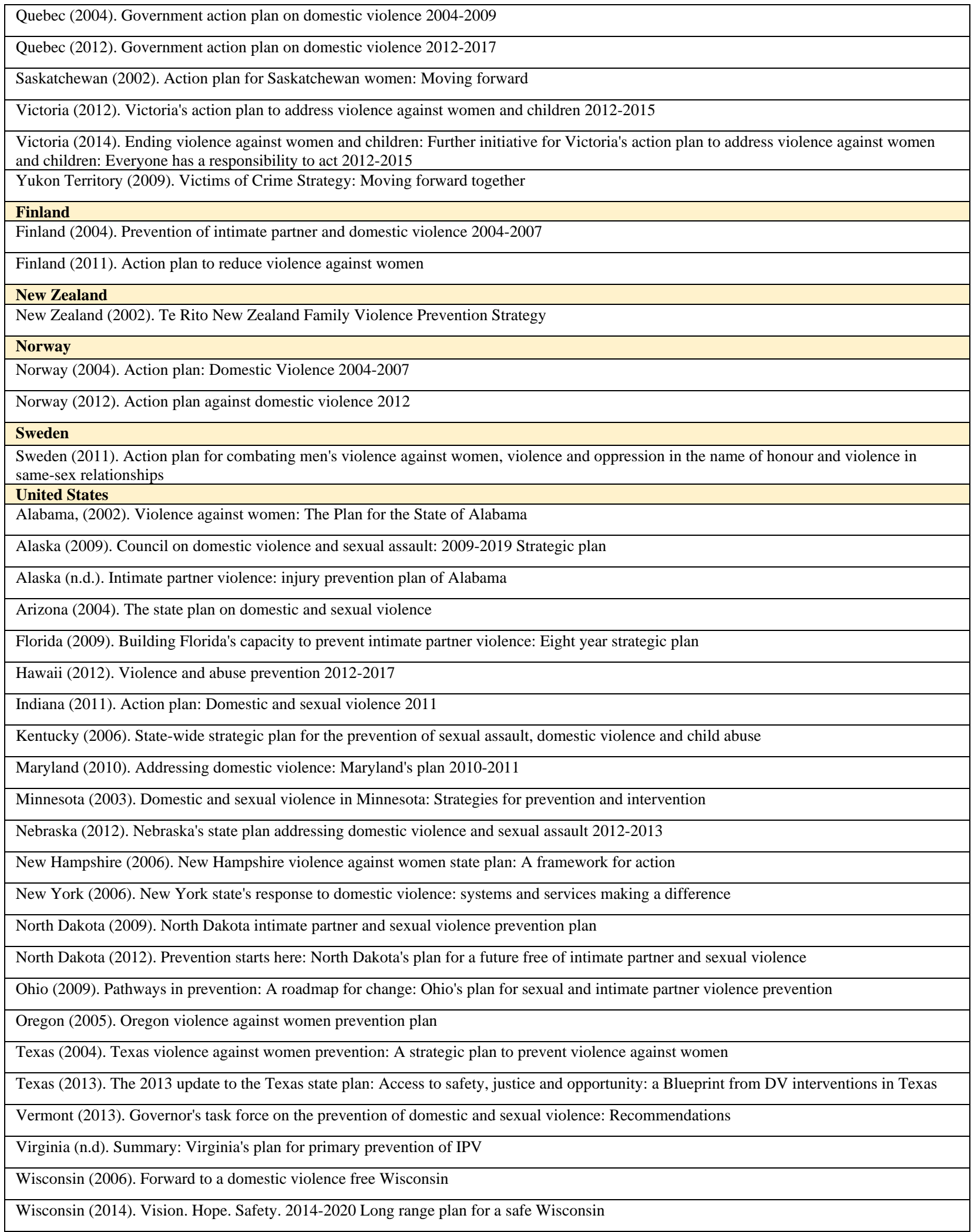




\begin{tabular}{ll}
\hline Main theme & Description \\
\hline Acknowledgment & $\begin{array}{l}\text { Did government plans acknowledge Indigenous peoples? How were } \\
\text { they acknowledged? }\end{array}$ \\
\hline Causes/Theories of DV & $\begin{array}{l}\text { Any description about causes or theories about why DV occurs in } \\
\text { Indigenous communities? }\end{array}$ \\
\hline Structural Factors & $\begin{array}{l}\text { Factors that are related to the current environment of Indigenous } \\
\text { peoples and may contribute to DV. }\end{array}$ \\
\hline Strategies/Actions & $\begin{array}{l}\text { What strategies and actions were identified to prevent DV amongst } \\
\text { Indigenous women, peoples/communities? }\end{array}$ \\
\hline
\end{tabular}

Table 1: Main coding themes 
Bios

Sarah Fotheringham is a research and evaluation consultant in the social services sector and an instructor at the University of Calgary, Faculty of Social Work. She has been working in the nonprofit sector in a range of capacities including in program development, research and policy for over 18 years. Sarah has a PhD from the University of Calgary, Faculty of Social Work and is a Registered Social Worker with the Alberta Council of Social Workers. Areas of specialty include violence against women, poverty, community economic development, and social enterprise.

Lana Wells is the Brenda Strafford Chair in the Prevention of Domestic Violence and Associate Professor at the Faculty of Social Work, Fellow, and Faculty Member of the School of Public Policy, University of Calgary, Canada. She is currently leading Shift: The Project to End Domestic Violence (www.preventdomesticviolence.ca). Shift’s purpose is to develop, implement, and scale up best and promising primary prevention practices, strategies, and actions in partnership with government, systems, community leaders, and NGO's with the goal of preventing domestic violence before it starts.

Sharon Goulet is a Red River Métis and member of the Métis Nation of Alberta. Sharon has lived in Calgary for 30 years, and has worked at the City of Calgary for the past 24 years in a variety of positions that support and advocate social change for Indigenous Calgarians. Presently, Sharon is a Social Planner with Family \& Community Support Services, and her work involves social planning, community development, research, and advocacy on issues that concern the Indigenous urban community. Sharon completed her Master's degree in 2005 at the University of Calgary with a focus on Indigenous leadership, and is considering a $\mathrm{PhD}$, with a research interest in understanding Métis Identity. 